\title{
Oesophageal stent-associated esophagorespiratory fistula
}

\author{
Karan Madan, ${ }^{1}$ Arun Venuthurimilli, ${ }^{2}$ Anant Mohan, ${ }^{1}$ Randeep Guleria ${ }^{1}$
}

${ }^{1}$ Department of Pulmonary Medicine and Sleep Disorders, All India Institute of Medical Sciences, New Delhi, India ${ }^{2}$ Department of GI Surgery, All India Institute of Medical Sciences, New Delhi, India

\section{Correspondence to}

Dr Karan Madan

drkaranmadan@gmail.com

Accepted 23 August 2015

\section{(a) CrossMark}

To cite: Madan $\mathrm{K}$ Venuthurimilli A, Mohan A, et al. BMJ Case Rep Published online: [please include Day Month Year] doi:10.1136/bcr-2015211880

\section{DESCRIPTION}

A 79-year-old man underwent oesophageal selfexpanding metal stent (SEMS) insertion for palliation of advanced squamous cell carcinoma of the mid-oesophagus. Nine months later, a second oesophageal SEMS placement (stent in stent) was performed due to tumour obstruction of the first SEMS. After 8 months following a stable course, the patient developed intractable coughing and copious expectoration following meals.

Barium swallow examination demonstrated spill over of the oesophageal contrast into the trachea, indicative of tracheo-oesophageal communication (figure 1A, B), and CT demonstrated the upper end of the oesophageal stent communicating with the trachea (figure 1C). Flexible bronchoscopy examination demonstrated complete prolapse of the upper

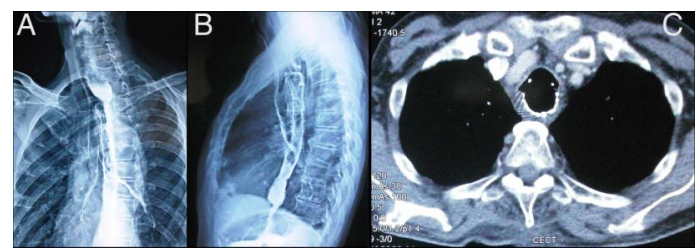

Figure 1 Posteroanterior (A) and lateral (B) images obtained during barium swallow examination demonstrating spillage of contrast into the trachea. CT image $(C)$ demonstrating the upper end of the self-expanding metal stent lying within the upper trachea.

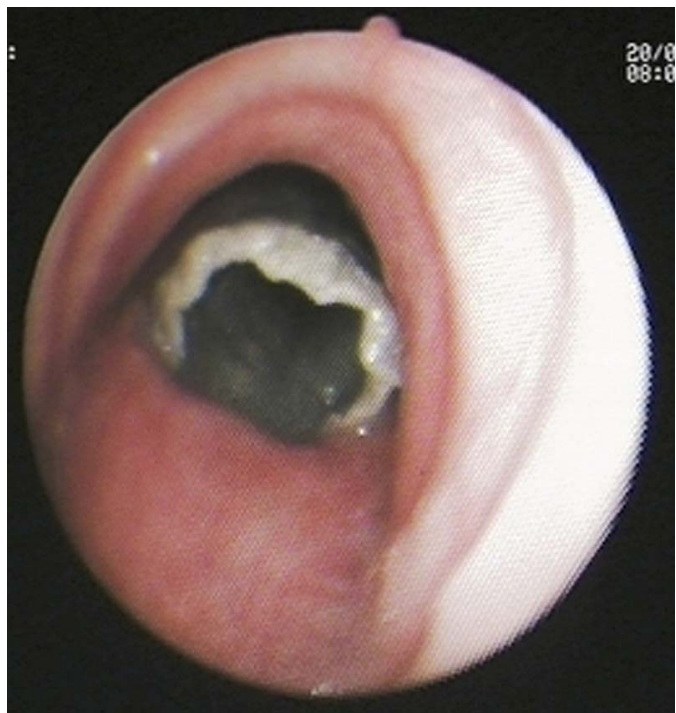

Figure 2 Flexible bronchoscopy image demonstrating completely prolapsed oesophageal stent lying within and causing significant compromise of the airway lumen.

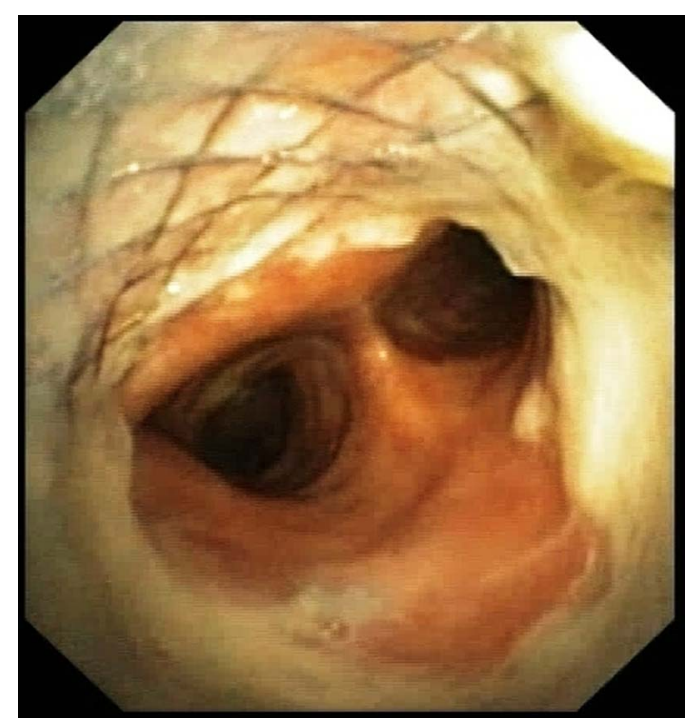

Figure 3 Deployment of a tracheal SEMS, the carina is normally visualized.

end of the oesophageal SEMS into the upper trachea confirming a diagnosis of stent-associated esophagorespiratory fistula (SERF). The prolapsed stent was causing approximately $80 \%$ compromise of the tracheal lumen (figure 2). Urgent rigid bronchoscopy was performed and a covered tracheal SEMS was deployed to completely seal the tracheo-oesophageal communication and achieve tracheal patency (figure 3). The patient experienced immediate resolution of symptoms following tracheal stenting.

Tracheal erosion and prolapse of oesophageal metal stents leading to SERF are unusual complications. ${ }^{1}$ They can lead to life-threatening airway obstruction or aspiration. Parallel tracheal and oesophageal stenting, as was eventually performed in our patient, is a useful modality in palliation of patients with advanced oesophageal cancer. ${ }^{2}$

\section{Learning points}

- Tracheal erosion and tracheal prolapse of oesophageal metal stents are rare complications.

- Parallel tracheal and oesophageal stenting is a useful modality in palliation of patients with advanced oesophageal cancer.

Contributors KM was involved in flexible bronchoscopy, trachea stenting and manuscript preparation. AV participated in patient 
management and follow-up. AM was responsible for flexible bronchoscopy and manuscript review. RG was involved in manuscript review.

Competing interests None declared.

Patient consent Obtained.

Provenance and peer review Not commissioned; externally peer reviewed.

\section{REFERENCES}

1 Madan K, Venuthurimilli A, Ahuja V, et al. Tracheal penetration and tracheoesophageal fistula caused by an esophageal self-expanding metallic stent. Case Rep Pulmonol 2014;2014:567582.

2 Schweigert M, Posada-González M, Dubecz A, et al. Recurrent oesophageal cancer complicated by tracheo-oesophageal fistula: improved palliation by means of parallel tracheal and oesophageal stenting. Interact Cardiovasc Thorac Surg 2014;18:190-6.

Copyright 2015 BMJ Publishing Group. All rights reserved. For permission to reuse any of this content visit http://group.bmj.com/group/rights-licensing/permissions.

BMJ Case Report Fellows may re-use this article for personal use and teaching without any further permission.

Become a Fellow of BMJ Case Reports today and you can:

- Submit as many cases as you like

- Enjoy fast sympathetic peer review and rapid publication of accepted articles

- Access all the published articles

- Re-use any of the published material for personal use and teaching without further permission

For information on Institutional Fellowships contact consortiasales@bmjgroup.com

Visit casereports.bmj.com for more articles like this and to become a Fellow 